\title{
DETERMINATION OF ELECTIVE COURSES BY THE METHOD OF ANALYTICAL HIERARCHY PROCESS AND AN APPLICATION IN TOURISM FACULTIES
}

\author{
Münevver Çicekdagi ${ }^{1}$ \\ Abdullah Karaman
}

\begin{abstract}
It is observed that course programs are divided into two as obligatory and elective courses in faculties. Obligatory courses are the ones, which the students have to take for being able to graduate from their school. Elective courses are the ones, which can be taken according to the choices of the schools or students. Other than obligatory courses, giving the possibility to choose the courses they can take to the students is also appropriate approach for democratic understanding of today. It is accepted that elective courses prepare the students for the life and that they are useful in revealing their interests and abilities. Presenting different alternatives to the students will also help them develop positive attitudes toward school. The aim of this study is to help lecturers make the most proper decisions to the elective courses to be opened in travel and tourism management guidance departments of tourism faculties. Application was made to the lecturers of tourism faculty, and the performance of 5 alternative elective courses to be taught to the undergraduates over 4 years was assessed by using the method of Analytical Hierarchy Process (AHP), one of multi criteria decision making. During analysis of the data, package program called Super Decision was utilized. As a result of analysis made, the priorities of alternative elective courses were identified according to 3 different criteria. Following the studies, the results obtained were shared with the authorized people of the relevant department.
\end{abstract}

Key words: Elective Courses, Analytical Hierarchy Process, Tourism Faculties

\section{INTRODUCTION}

Education forms the essence of investment to human resource. In this scope, education comes to our face as a principal way of obtaining high level life for individuals and development and improvement and taking place among contemporary countries for societies (Hergüner vd., 2002: 45). Education, raising qualified human power having knowledge and skill especially industrial and service sector need and making employees more productive, makes ,important contribution to economic growth(Woodhall, 1979: 34). In the light of this information, education was defined as planned actions system serving to provide certain developments in human behaviors in the direction of aims "(Karsl1, 2003: 9)

Tourism education is evaluated in vocational and technical education. Vocational and technical education was defined as "in the integrity of national education system, together with industrial, agricultural and service sectors, planning, studying, developing organizing, coordinating every sort of national and technical education

${ }^{1}$ Lecturer, Selçuk University, munevverylmz@ gmail.com 
services and whole of management, supervision, and instruction actions " (Şahin ve Find1k, 2008: 65)

In this direction, the main aim of tourism education institutes, subjecting staff who is going to work in tourism sector to basic education, is to bring tourism consciousness and philosophy in all of those receiving education; contribute to development of tourism sector; and provide qualified staff to tourism sector (Misirl1, 2002: 42); and teaching managerial techniques, to adapt to the approach becoming dominant and acceptable in the world and raise top level tourism professionals to be able to comprehend the new concepts, opinions, and technologies (Üzümcü ve Bayraktar, 2004: 80). Shortly, tourism education, teaching tourism movement and economy to people and young people that study, is whole of the efforts aiming to raise wellinformed and qualified staff and manager for tourism (Hacıoğlu, 1992: 92; Sezgin, 2001: 135).

Educational process have to incorporate the qualities such as application, being economic, becoming preparative for the life by adapting to the developments, being society and sector -oriented, etc.( Alkan et al., 1996: 17) Otherwise, no matter how adequate infrastructural investments in tourism area are, as long as they are not supported by tourism education, which forms the most important element in social superstructure institutes, they will not provide any benefit (Tuyluoğlu, 2003: 10).

With giving education, which is appropriate for the interests and abilities of the students, very great developments can be experienced regarding the technology, science, and art. That obligatory courses as well as elective courses are present in our schools supports this thought. It is accepted that elective courses prepare the students for the life and are useful in revealing their interests and abilities. Therefore, it is observed that course programs in the schools are divided into two as obligatory and elective courses (EARGED, 2008).

Beside the obligatory courses, giving the opportunity to the select the courses the student who will learn is a suitable approach for understanding of the democracy and freedom at the present days. As stated by Genç ve Kalafat, (2007: 11), one of the main components of democracy is to meet the differences with toleranse. Presenting the various alternatives to student will be helpful the student to develop the positive attitudes toward school. Our age is a period, in which the important developments in world history have been fastly experienced. Elective courses support the developments of the students as unseparable part of school programs. Elective courses contributes to the cognitive (knowledge and skill), sensorial (interest, attitude) and social developments (EARGED, 2008).

According to (Variş, 1976: 113-114), the functions of elective courses help the students prepare for occupation and business arass, the interests, needs, and abilities of the students provide to give place during their educations, talented students provide to be able to specialize in a certain subject and the goals of school to be realized.

Making decision is generally a process to select the most suitable, possible one or several options from option set in direction of at least one purpose and based on a 
criterion. According to this, the process of making decision includes the elements such as decision maker, options, criteria, environmental effects, priorities of decision maker and results of decisions. The process can end in the form of that decision maker makes a selection, ordering, or classification from among the existing options. In this stage, in order to make the most accurate decision, multi- criteria decision methods come to our face. The methods of multi -criteria decision, in which the dual comparisons of certain criteria are based on help to make the most accurate with numerical data (Evren ve Ülengin, 1992)

\section{THEORETICAL INFRASTRUCTURE}

There are a few number of studies about elective courses having an important function regarding diversification of education. In some of these studies (Demir, 1995; Kuzgun vd., 1989; Tümkaya, 1990), the issue of elective course was indirectly discussed. Namely, Kuzgun (1989), in the study he carried out the duties of academic consultants in Ankara University, revealed that although both lecturers and students consider the item "introducing the content of elective courses and helping the students select accurately" as duty of academic consultant, the students could not receive this service. That is, it was seen that academic consultants did not adequately give service about elective courses to the students

Paykoç et al. (1989) stated the aims of students of Educational Faculty in receiving elective course about non-technical selective courses as "developing specific interest areas" (73\%), "developing general culture" (63\%), personality/developing social relationship (43\%), and developing English language (27\%). The aims emphasized the most by heads of department have become as developing specific interest areas and developing general culture. In addition, they reported the aims such as information acquiring in the other areas, contribution to vocational development, closing course deficit. The problems observed in taking elective course are lack of sufficent quantity of elective course, courses that are not compatible with the aim in terms of quality, and remaining of a number of students uncovered. In addition, among the other problems observed, the subjects such as elimination of elective course philosophy and understanding, inadequacy of lecturers, limited students quotas, lack of elective course desired by the student are counted. The students have the right to take education in the direction of their interests and abilities. The responsibility of educational institutes is to prepare educational programs that will provide eductaional oppportunity to the students having different characters according to their interest aras. In the preparation of educational programs, elective courses should be determined by considering demands of the students (Ülgen, 1992) . However, in the application of elective course system, some problems can be experienced. The students complain about information deficiency. Informing is not made adequately and in time. Congestions can emerge in the selection of elective course. Hence, every students cannot select the course he/she wants (Demir, 1996). Elective courses should have diversity to respond the demands of the students. Informing about elective courses should be made in time and adequately (Demir ve Ok, 1996). 
Human being comes to face with many decisions in every stage of his/her life. Therefore, being able to make healthy decisions makes it necessary to correctly relate the interactions taking place in all system or subsystems in the direction of the aim(s) determined (Evren ve Ülengin, 1992). Every options have the effects that can be directly seen as well as the effects that can be noticed but not be quantitatively expressed. Reflecting the analysis of these the existent system and determining the option having the most contribution in total both force decision maker and takes more time. Decision maker mostly considers these factors intuitionally (Yuluğkural, 2001). While solving a decision problem, the better the model made represents the real system, the more the reliability of the results obtained increase. Especially beside quantitative factors, also considering qualitative factors will enable the results to be more realistic (Kocakalay vd., 2004).

In university education, the students take obligatory courses as a requirement of the programs they study. Beside these courses, they can also take elective courses related to their vocational interest areas and personal abilities. As a result of increase of technological development and knowledge, that students become specialist according to their interest rates and develop their personal abilities have gained importance. In university, for students to be able to develop better themselves, the applications of elective course system are made.

The aim of this study is to help lecturers make the most appropriate decision about elective courses to be opened in the Departments of Travel Business Management and Tour Guiding of Tourism Faculties. Application was administered to lecturers of Tourism Faculty and the performance of 5 alternative elective courses getting the highest points undergraduate students are going to study over 4 years are evaluated by using Analytic Hierarchy Process (AHP), one of multi -criteria decision methods. During analysis of the data, the program called Super Decision was utilized. As a result of the analysis carried out, the priorities of elective courses were determined according to the different criteria. The results obtained following the study were shared with the authorities of the relevant department.

\section{ELECTIVE COURSES}

Elective courses support the developments of the students as inseparable part of school programs. Elective courses make contribution to the cognitive, (knowledge, skill) sensorial (interest, attitude), and social developments of the students. The options of different course are presented to the students having the different interests, needs, abilities, and skills. Elective courses are also expected to have a features to bring life skills in the students. In our world developing in unbelievable speed, for our students to be able to keep in step with this change, it is necessary to also change their life skills (EARGED, 2008).

It is seen that there are two different applications in the world about elective course. The first of these is especially application in USA. In this country, elective courses have an aim revealing and developing of the interests and abilities of the students. The second sort of application is met especially in European countries. In some countries, elective courses are used to give some courses in the problematic areas 
from the social point view. These are generally religious, historical, and linguistic courses (Taş, 2004).

That the required conditions in the requirement are increasingly based on the information and skills that will require specialism has made it obligatory that school duties increase by becoming diversified and that education in the school is carried out clearly and interruptedly in such a way that it will keep in the developing technology (Tan vd., 2002: 8). Therefore, if the elective courses are effectively evaluated, the students are identified in the framework of their interests and abilities and can be raised in the different vocational branches as competent individuals. This also becomes fact with effectively applying the courses.

In the classes the students having the different interest, needs, and abilities take. This case reveals it is necessary to be presented the different options that are suitable for each learner in the group. For the students needing multi-dimensional and a large learning diversities to be able to meet their own needs in teaching -learning activities and to organize information by absorbing in the direction of their own schemes, it is necessary to adjust the system according to this. In addition, perceiving students according to discrimination of sorts of intelligence; designing education in the way that it will accept every kind of students; and spreading this design over the base all over the world should be considered (Sarigöz, 2009).

In the selection process of elective courses, the problems school managers face with are (Eşbahoğlu, 2015):

1. Due to the fact that the number of elective courses are more, it revealed that there is no sufficient number of classroom.

2. In the schools carrying out double shift schooling, it emerged that there is no sufficient number of classrooms for elective courses.

3. It emerged that there was no teacher in adequacy to be able to give elective courses

4. Since there is no in sufficient number of classroom, it emerged that classrooms were crowded.

5. Due to the fact that there are no sufficient number of classrooms and teacher, student's guardians experience problems. The problems the teachers face with in the selection process of elective courses:

1. It emerged that the textbooks and materials belonging to elective courses were not present.

2. Due to the fact that the classrooms of elective course are crowded, the problems emerged.

3. The problems with the indifferent students coming to the courses they do not want were experienced in teaching course.

4. It emerged that the teachers did not take any in-service education, and they carried out a course in close branch.

5. It emerged the view that assessment with grade increased worry in some students 


\section{MAKING DECISION WITH AHP (ANALYTIC HIERARCHY PROCESS)}

Human beings are obliged to continuously decide in either their individual activities or as a requirement of their duties and solve their problems. Problems emerges when the conditions of the real situation is different from desired situation. Sometimes, in contrast to that expected, problems help new opportunities create. In these cases, while the manager solves the problem, on the one hand, he/she considers opportunities, on the other hand. In solving process a certain problem, manager has to make many decisions. Making decision is to identify the most suitable option from among action style with its the simplest definitions. Each decision makes it necessary decision needs together with it and activities regarding solving problem. In respect of these features of it, problem solving and making decision play key role in the activities of manager. This key role is remarkable especially related to planning function, because in planning, instead of daily decisions, what is under consideration is more long -termed and important decisions (Özkan, 2007).

Analytic Hierarchy Process was developed by Thomas L. Saaty in 1971. Saaty, transforming AHP into a model in 1977, facilitates the solution in deciding problems (Rençber, 2010: 34). The main aim of AHP is to make contribution to the solution of multi-criteria decision problem. Analytic hierarchy process (AHP) is one of multicriteria decision methods and is not a magic solution method or model reaching to the right answer is a process helping decision makers to find "the best answer" (Forman ve Selly, 2002: 14)..

AHP is a measurement theory based on alternatives to be compared to a common criterion. AHP provides important aids to decision maker in concluding multicriteria and multi-option problems. AHP problem is formed with a hierarchic structure consisting of more than one levels. In analytic hierarchy process, a hierarchical structure consisting of aim, criterion, possible sub criterion levels, and alternatives is used (Saaty, 1990: 9-11). It is a general method for the problems that are complicated, difficult to understand or unstructured. It was built on three main principles as forming hierarchies, determining advantages, and logical and numerical consistency (Güner ve Yücel, 2007: 74).

In AHP, problem is hierarchically structured. In the figure, a three levels hierarchical structure is seen. An aim takes place on the top of hierarchy and, the structure is completed in such a way that criteria will take place below the aim and alternatives at the bottom (Felek vd., 2007: 7). 


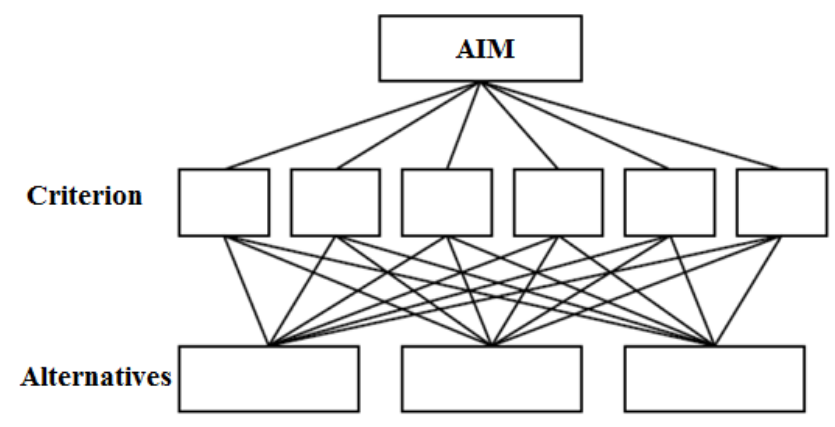

Source: (Saaty ve Vargas, 2012)

Figure 1: Three Level Analytic Hierarchy Model

After hierarchy is formed, relative significance levels of criteria versus each other are calculated. Decision maker decides significance degree between criteria based on 1 to 9 scale. 1-9 scale utilized is explained in detail in the table (Saaty, 2008: 257).

Table 1: 1-9 Scale Used in Dual Comparison Method

\begin{tabular}{cl}
\hline Intensity of importance & \multicolumn{1}{c}{ Definition } \\
\hline 1 & Equal importance \\
\hline 3 & Somewhat more important \\
\hline 5 & Much more important \\
\hline 7 & Very much more important \\
\hline 9 & Absolutely more important \\
\hline $2,4,6,8$ & Intermediate values
\end{tabular}

Kaynak: (Saaty, 2008)

While two criteria or alternatives are dually compared in any level of hierarchy, decision maker utilizes dual comparison rule taking place in the table. For example, while $\mathrm{A}$ and $\mathrm{B}$ criteria taking place in the hierarchy or their alternatives are compared to each other, if $\mathrm{X}$ is a little more significant compared to $\mathrm{Y}$, according to Table 1 , the relative value of $\mathrm{A}$ compared to $\mathrm{B}$ will be axy $=3$. In this case, according to theoretical fundamentals of AHP technique, the relative significance value of $\mathrm{B}$ compared to $\mathrm{A}$ will be ayx $=1 / 3$. What is wanted to be stated here is that if decision maker considers that an element is 3 points more significant compared to the other element, he/she also accepts the mathematical reverse of this. So, any level of hierarchy has elements in the number of " $n$ ", it will be necessary to make comparison as many as dual combination of " $n$ " (n(n-1)/2) for that level. All of these comparison values are expressed in the form of square matrix. Thomas Saaty suggests to directly make a face to face survey with the relevant people and take their views regarding dual comparisons, in using AHP technique. 
The relevant person(s) of interest should be the person(s) who knows the subject or is familiar to it, even if they are absolutely specialist on the subject (Kaplan, 2010).

AHP was not designed to replace with the transparent thought given by decision makers. Despite this, AHP better organizes the thoughts of decision makers and performs more straightly than others. The real power of AHP is that most decision makers dealt with the complex and difficult decisions like a system. Limited logicalness and restricted conceptual processes almost makes it impossible to thoroughly take into consideration all factors in complex decisions for decision makers. Decision support methodologies like AHP, not understanding the related weights of the important criterion, is based on its subset. AHP enables complex decision processes to be more rational in the synthesis of all information existing in a system area and about decision in systematic style (Handfield vd., 2002).

\section{APPLICATION}

The study was carried out to determine the elective courses as criterion -based. First of all, in order to determine the selection criteria of elective courses, literature reviews were carried out and, assessing the views of the competent people and relevant lecturers and administering survey to lecturers of Department of Travel Business Management through the pool regarding why elective courses are necessary to be studied, 4 criteria were identified. In the second stage, the elective courses present in Tourism Faculties of University were collected in a single pool and a survey was administered to the same lecturers and the most important 5 courses were identified. Identification of selective courses were evaluated by using AHP method with individually dual comparison matrices for all purposes. As a result of the analysis of data, the important purposes will be both identified and identifying of purpose-based elective courses will be provided.

Package program called Super Decision will be utilized in the analyses to be made In any decision problem, four different analyses can be made to support decision makers. These analyses can be made as (Uyanık, 2005);

- $\quad$ Putting in order the alternatives from the best to the worst.

- Identifying the best alternative or selecting the series of the best alternatives in limited number

- Identifying the main distinctive characteristics of the alternatives and defining then according to these characteristics

- $\quad$ Dividing alternatives into the previously identified homogenous groups

The aim of this study is to select an application that is multi- criteria problem having a interrupted decision area by putting in order alternatives from the best to the worst. "Analytic Hierarchy Process (AHP) was selected for this study due to the fact that it draws a framework, in which decision makers can structure problems in reaching the best possible results and can analyze the target, important points and alternatives to them, and that it provides a framework in making decision or solving problem for group participation from among many "Multi-Criteria Decision Method "that can be used to put in order alternatives. This method, due to the fact that it is understandable and easy to apply it, is the one frequently preferred by decision makers and, when it is applied in the right areas and accurately, it gives considerably 
effective results. In addition, for obtaining all stages of AHP rapidly and easily, the software called "Super Decision". Working procedure was summarized in the following Figure 2.

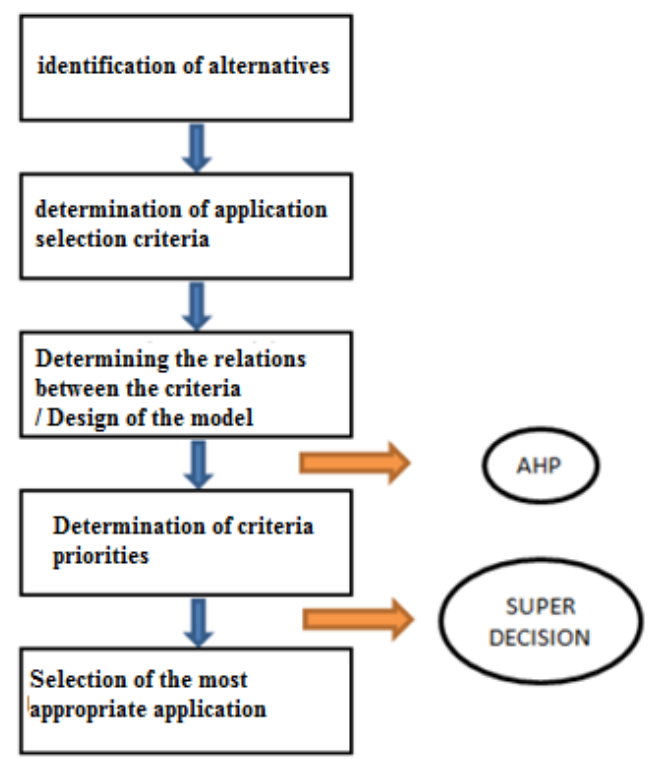

Figure 2: AHP application procedure (Kaplan, 2010)

\section{Determination of Decision Alternatives;}

While the alternatives within the study are determined, first of all, the needs for the students of Tourism Faculty in their lives during and after education were determined. The elective courses to be determined in this scope were written by bringing together elective courses studied in Tourism Faculties of domestic and foreign universities and considering as possible as the most comprehensively and alternatively by the specialist people giving education in this area. Bringing together all courses and combining the similar courses, a course list of a total of 87 courses was prepared. That there are more alternative consists of the main subject of the study. These courses, being filtrated a survey prepared in the form of "Select the most important 10 courses shown in Table 2 by lecturers of the Department of Travel Business and Tour Guiding of Tourism Faculty ", the most important ones were put in order. What is aimed in the scope of the study is to enable them to take education with appropriate courses for raising a qualified individual, student, and tourism professional, not the course to be taught the most easily. Here, the importance of AHP emerges. 
Table 2: Elective Courses determined according to priority order

\begin{tabular}{|c|c|c|}
\hline $\begin{array}{c}\text { Order of } \\
\text { importance }\end{array}$ & Course title & $\begin{array}{c}\text { The number of } \\
\text { lecturers who } \\
\text { suggest Course }\end{array}$ \\
\hline $\mathbf{1}$ & Vocational English & 6 \\
\hline $\mathbf{2}$ & History of Anatolian Civilizations & 6 \\
\hline $\mathbf{3}$ & Management of Customer Relationship & 4 \\
\hline $\mathbf{4}$ & Destination Management & 4 \\
\hline $\mathbf{5}$ & World Tourism Movements & 4 \\
\hline $\mathbf{6}$ & German & 3 \\
\hline $\mathbf{7}$ & Tour Planning and Management & 3 \\
\hline $\mathbf{8}$ & Turkish History and Culture & 3 \\
\hline $\mathbf{9}$ & History of Art & 2 \\
\hline $\mathbf{1 0}$ & Arabic & 3 \\
\hline
\end{tabular}

As will be understood from the Table 2, the course cared the most has been Vocational English This is followed by History of Anatolian Civilizations, Management of Customer Relationship, Destination Management, World Tourism Movements, German, Tour Planning and Management, Turkish History and Culture, History of Art, and Arabic. All of these 10 courses have importance, because it was identified by voting from the selection list of 87 courses. The top 5 courses taking the most point will be prioritized by being subjected to survey after model is established by cross dual survey evaluation in the scope of AHP.

\section{Determination of Selection Criteria;}

While selection criteria aimed is determined, it was utilized from articles in literature, articles in the literature, internet resources, specialist people and, the most important one, from the suggestions of lecturers of Tourism Faculty. Considering the question "Which course the student of tourism faculty should select and why?", a list of purpose was prepared. Since there were no much more about the subject, all purposes obtained were put in order in such a way that it will with priority form 29 items. After ordering, with the result of survey administered to lecturers of Tourism Faculty for selecting 10 items with priority, the list of 29 items were reduced to 10 items. 
Table 3: The criteria aimed while determining elective course identified according to priority order.

\begin{tabular}{|c|c|c|}
\hline $\begin{array}{l}\text { Significance } \\
\text { Order }\end{array}$ & The criteria aimed at elective course & $\begin{array}{c}\text { The } \\
\text { number of } \\
\text { lecturers } \\
\text { suggesting } \\
\text { the } \\
\text { purpose }\end{array}$ \\
\hline 1 & $\begin{array}{l}\text { That the student brings in information and skill thanks to the } \\
\text { course }\end{array}$ & 9 \\
\hline 2 & Applicability of the course in the real life & 8 \\
\hline 3 & $\begin{array}{l}\text { Raising individuals who know what they do, what imagine, } \\
\text { and what can newly do according to the needs of the society in } \\
\text { their lives }\end{array}$ & 8 \\
\hline 4 & That the course is for application in the tourism area & 7 \\
\hline 5 & $\begin{array}{l}\text { That it presents the opportunity to develop themselves to the } \\
\text { students, whose areas and abilities are different, in the } \\
\text { direction of their preferences. }\end{array}$ & 6 \\
\hline 6 & $\begin{array}{l}\text { That it will encourage the students to entrepreneurship and } \\
\text { productivity }\end{array}$ & 6 \\
\hline 7 & Improving knowledge of the students in actual life & 5 \\
\hline 8 & $\begin{array}{l}\text { Bringing scientific look in the students by developing their } \\
\text { skills to question, observe, think critically, solve problem, and } \\
\text { decide }\end{array}$ & 5 \\
\hline 9 & $\begin{array}{l}\text { Enabling students to develop the attitudes and values } \\
\text { protecting mutual utility for them and the society they live in }\end{array}$ & 5 \\
\hline 10 & $\begin{array}{l}\text { Thanks to the elective course taken after graduation, job } \\
\text { opportunities to be acquired }\end{array}$ & 4 \\
\hline
\end{tabular}

As also stated in the part of literature, there are many aims of tourism education. In these aims, what is primary is to raise a qualified individual. The courses the student will take over his/her educational life will help him/her become a qualified individual. Since the aims are put in order for determining these courses, the aim receiving the most scores has become "That the student brings in knowledge, skill, and competent thanks to selective courses". This is followed by "Applicability of the course in the real life"; " Raising individuals who know what they do, what imagine, and what can newly do according to the needs of the society in their lives", "That the course is for application in the tourism area", "That it presents the opportunity to 
develop themselves to the students, whose areas and abilities are different, in the direction of their preferences", "That it will encourage the students to entrepreneurship and productivity", "Improving knowledge of the students in actual life ", "Bringing scientific look in the students by developing their skills to question, observe, think critically, solve problem, and decide", "Enabling students to develop the attitudes and values protecting mutual utility for them and the society they live in", and "Thanks to the elective course taken after graduation, job opportunities to be acquired ". Each of these aims has very serious significance degree. From among 29 different purposes, making selection, the most significant 10 purposes were put in order. Of these purposes, the first 4 purposes taking the highest score will be subjected to survey and prioritized after setting up model with cross dual survey assessment in the scope AHP.

\section{Setting Up Model}

After the assessment of lecturers of Tourism Faculty, 4 selection criteria determined were grouped and a model was formed. While this model is formed, beside the specialists in the sector, lectures of Tourism Faculty were also utilized. In the direction of their views, model was finally set up through 4 criteria and 5 alternatives and this model set up is shown in the following figure:

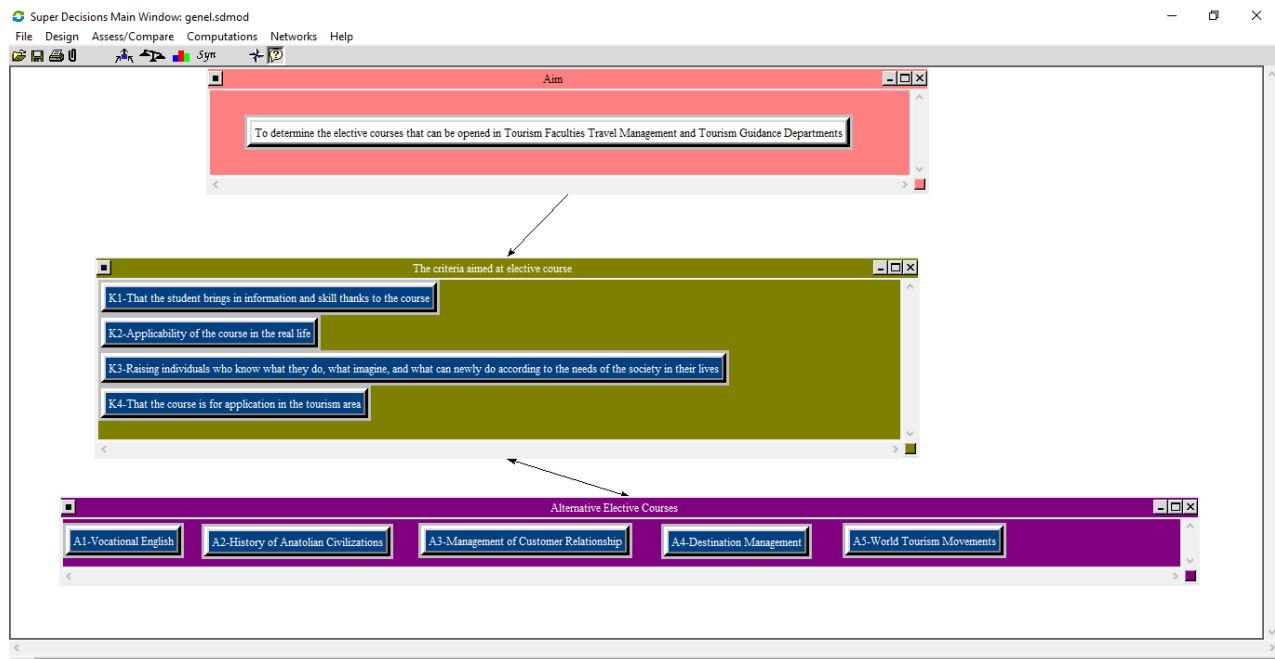

Figure 3: Study Model: Display Image of Super Decision Program

For determining the priority of each factor in the model obtained, AHP technique will be applied. For this, a study was prepared consisting of dual comparisons. Since survey is long, an application was made to 10 people from among lecturers of Tourism Faculty. During survey, one to one explanation of criteria was explained, while the specialists is present. 
Table 4: As a result of AHP Survey, All Answers People Gave and Information Table

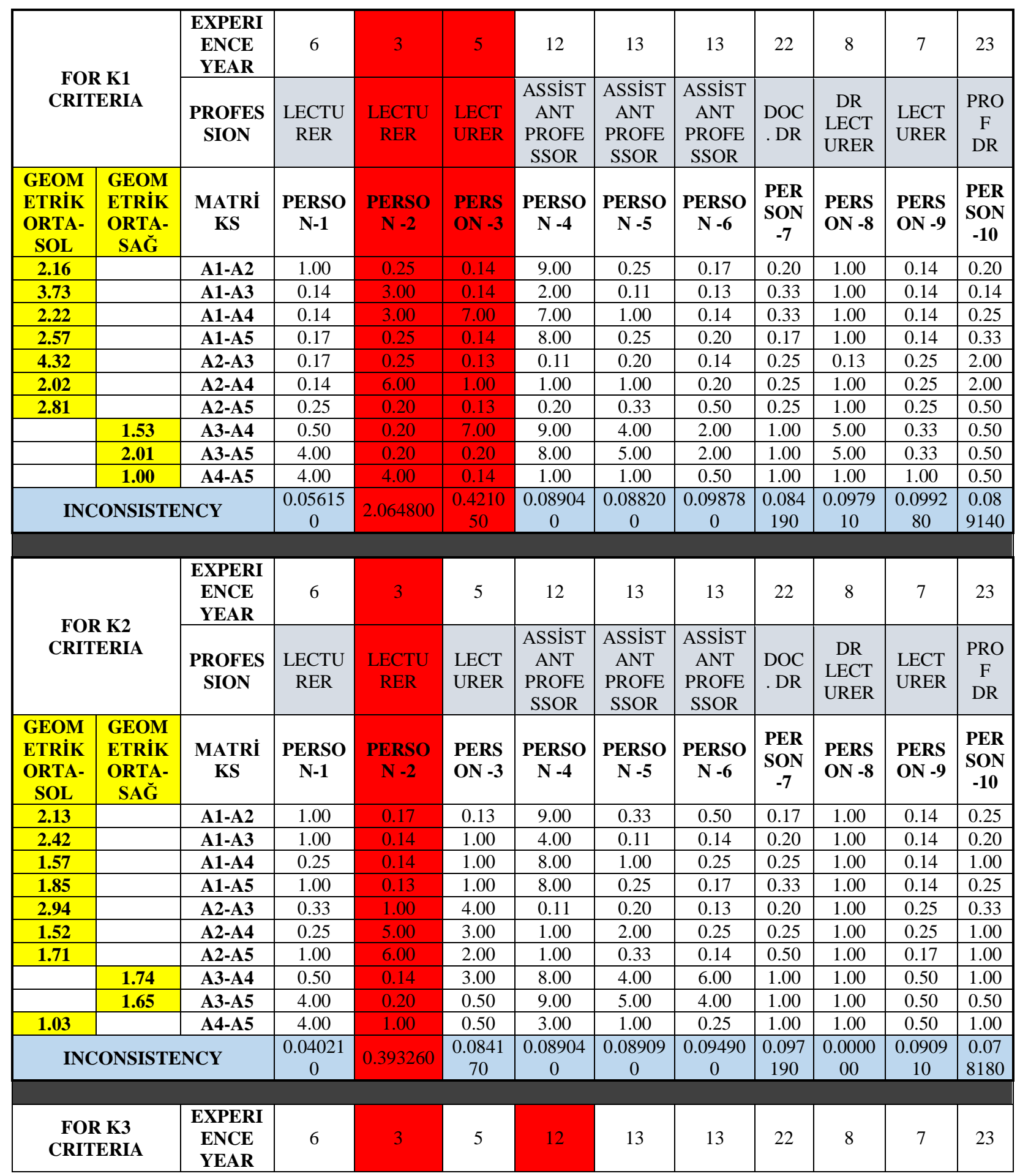




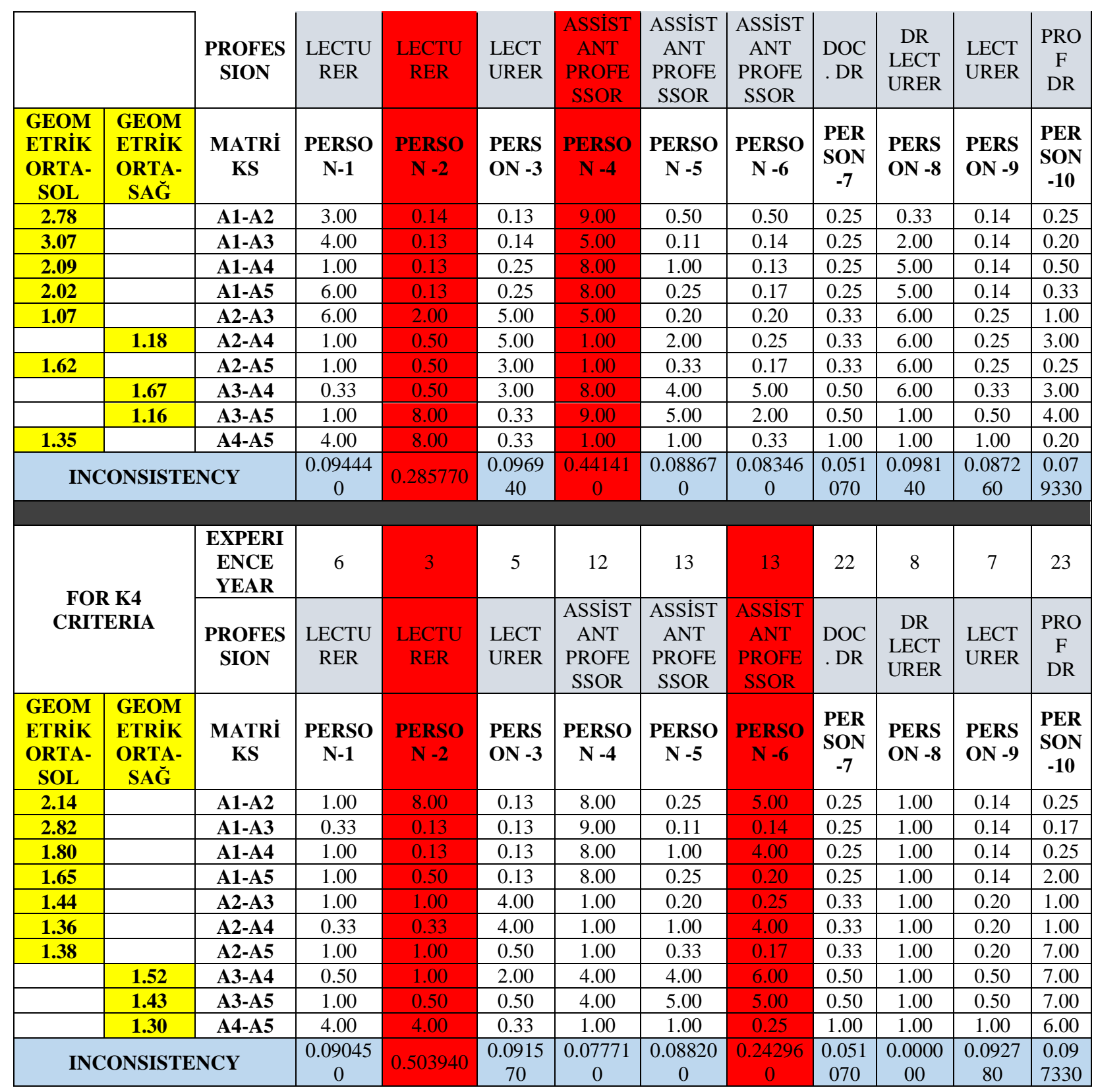




\section{Analysis of the Data}

The model presented in Table 3 and the results of survey carried out were analyzed by means of Super Decision package program. Taking geometric mean of points the specialists gave to the survey made, they were transferred to the program. Totally, with 4 different criteria, 40 pieces of dual comparison were made. As mentioned in the previous sections, in the working principle of AHP, it is necessary for consistency to equal to the value 0.1 or be smaller than this value. After survey inputs were completed, for the consistency of the answers given, "Basic Inconsistency Report" was utilized. According to the report, any inconsistency was not observed in the answers, hence, there was no need for repeating surveys. And it was observed that the data were reliable. The results of the people, whose inconsistency rates were under $10 \%$, were assessed. When the results forming in this scope are examined;

The matrix results formed for K1-"the criterion of "That the student brings in information and skill thanks to the course" are as follows

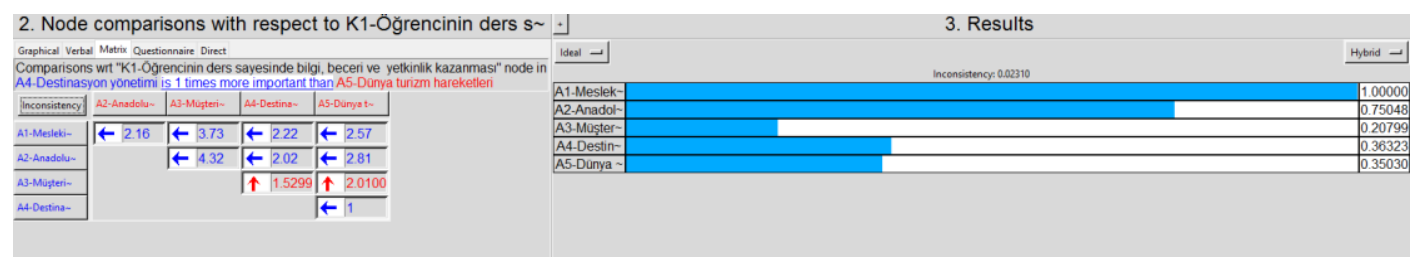

Figure 4 Matrix table for $\mathrm{K} 1$ criterion and display image of super decision program belonging to prioritization results

Table 4: K1 Prioritization classification of elective courses for K1 criterion

\begin{tabular}{|l|l|l|}
\hline \multicolumn{1}{|c|}{ Inconsistency } & \multicolumn{1}{|c|}{0.0231} & $\begin{array}{c}\text { K1- That the student brings } \\
\text { in information and skill } \\
\text { thanks to the course }\end{array}$ \\
\hline \multicolumn{1}{|c|}{ Name } & \multicolumn{1}{|c|}{ Normalized } & \multicolumn{1}{c|}{ Idealized } \\
\hline A1- Vocational English & 0.374250945 & 1 \\
\hline A2- History of Anatolian Civilizations & 0.28086635 & 0.750475994 \\
\hline A4- Destination Management & 0.135938756 & 0.363228892 \\
\hline A5- World Tourism Movements & 0.131101966 & 0.350304969 \\
\hline A3- Management of Customer Relationship & 0.077841984 & 0.207994087 \\
\hline
\end{tabular}

The highest point of $\mathrm{K} 1$ coded student, when 5 elective courses determined belonging to the criterion of "That the student brings in information and skill thanks to the course" are put in order, the course taking the highest point has been "Vocational English". This is followed by "History of Anatolian Civilizations", "Destination Management", and "World Tourism Movements". The selective course taking the least score has been the course of "Customer Relationship Management" 
When the results of $\mathrm{K} 1$-coded criterion "That the student brings in information and skill thanks to the course" are evaluated, the order of the top 5 elective courses was stated in Table 4. When regarded to this ordering, "Vocational English", with another definition, "Business English" took place in the first order getting the most points. Vocational English have a great importance for many vocational groups. English is extremely useful for those taking educations in the areas of human resources, tourism, marketing, advertising, law, insurance, and etc. or being in active business life. If you work in a cosmopolitan company, since you can daily be in communication with many partners, vocational English is an indispensable thing. Intercultural interaction is something that can be made with communication. Verbal communication is the most basic element of this interaction. Even if it is impossible to know all languages, knowing the language that world accepts and many people speak is a distinctive feature for the people during this interaction. Among these many languages, the most important one is English. English is an international language. That the people to vocationally survive in a natural process, reach achievement, be able to climb to top positions, and be able to create difference is directly proportional with the level of the language that they can speak. In this sense, vocational English has a great importance. Thanks to English that is international language, the knowledge and skill of the student will increase and it can be enabled him/her to be a competent person in his/her area.

In the criterion of "That the student brings in information and skill thanks to the course", the most second important elective course has been "History of Anatolian Civilization". This course has a great importance to the students studying in Travel Business Management and Tour Guiding of Tourism Faculty. For, Anatolia, in which many important civilizations lived over history, with tens of civilizations and tribes especially Hittites Frigs, and Urartians completely uncovered today, witnessed many "first" in history of the world. Anatolian Civilization that incorporate a mystery mentioned in tales and founded on the fertile land of East and West, departure point of philosophical thought, with the renewals and development they left legacy and brought to the world, took its place in the history. So, it can be seen that the civilizations in Anatolia, which saw the emergence of Eastern Mysticism, raised the pioneer people in the emergence of mathematics and geometry, and observed the unbelievable evolution of the knowledge transported from its East to its West, how helped to humankind in the development steps. Anatolian civilizations, until the covered and uncovered civilizations lying in the deepness of history, with the mystery it kept waiting also keep its value. That the student graduates from this department with this consciousness has a great importance. 
The matrix results formed for K2- "The criterion of Applicability of the course in the real life" are as follows:

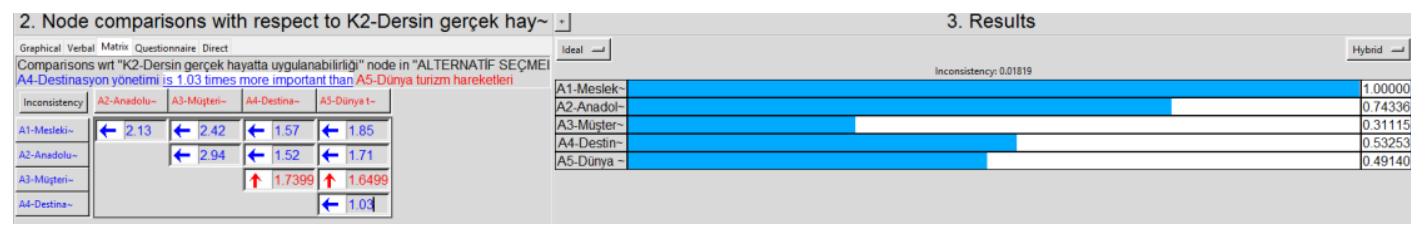

Figure 5: Display image of super decision program belonging to matrix table and prioritization results for $\mathrm{K} 2$ - criterion

Table 5: Prioritization ordering of elective courses for K2-criterion

\begin{tabular}{|l|l|l|}
\hline \multicolumn{1}{|c|}{ Inconsistency } & \multicolumn{1}{|c|}{0.01819} & $\begin{array}{l}\text { K2- Applicability of the } \\
\text { course in the real life }\end{array}$ \\
\hline Name & Normalized & Idealized \\
\hline A1- Vocational English & 0.324839949 & 1 \\
\hline A2- History of Anatolian Civilizations & 0.241471684 & 0.743355872 \\
\hline A4- Destination Management & 0.172988075 & 0.532533253 \\
\hline A5- World Tourism Movements & 0.159627727 & 0.491404234 \\
\hline A3- Management of Customer Relationship & 0.101072566 & 0.311145737 \\
\hline
\end{tabular}

According to the purpose of K2-the criterion of "Applicability of the course in the real life", when elective courses are also examined, the course "Vocational English" took place in the first order. Another remarkable result is that elective courses are put in the same order with the purpose of K1- "That the student brings in information and skill thanks to the course". This result can give the conclusion that the most important criterion for elective courses, in which both purposes are similar is that they are applicable to the real life and, thanks to this course, that the knowledge, skill, and competency are brought in.

The matrix results formed for K3- criterion of "Raising individuals who know what they do, what imagine, and what can newly do according to the needs of the society in their live" are as follows.

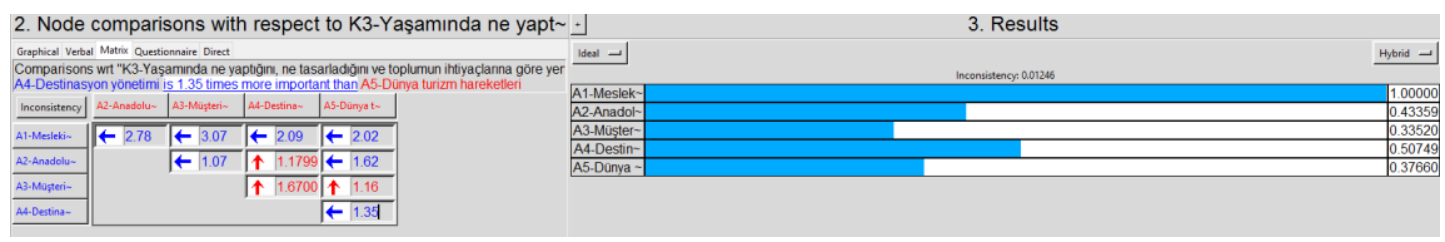

Figure 6: Display image of super decision program belonging to matrix table and prioritization results for $\mathrm{K} 3$ - criterion 
Table 6: Prioritization ordering of elective courses for K3-criterion

\begin{tabular}{|l|l|l|}
\hline \multicolumn{1}{|c|}{ Inconsistency } & & $\begin{array}{l}\text { K3- Raising individuals who } \\
\text { know what they do, what } \\
\text { imagine, and what can newly } \\
\text { do according to the needs of } \\
\text { the society in their live }\end{array}$ \\
\hline Name & 0.01246 & Idealized \\
\hline A1- Vocational English & Normalized & 1 \\
\hline A4- Destination Management & 0.376948819 & 0.507491565 \\
\hline A2- History of Anatolian Civilizations & 0.191298346 & 0.433586504 \\
\hline A5- World Tourism Movements & 0.163439921 & 0.376604959 \\
\hline A3- Management of Customer Relationship & 0.141960794 & 0.335197019 \\
\hline
\end{tabular}

Contemporary education is able to present the programs, which will bring in the necessary knowledge and skills in the individuals to shed light on the society of today and future and contribute "sustainable development" in every area. Foreign language overcame the simple level of use to respond daily requirements such as bread and water. It became an element of knowledge, trade, and intercultural communication, integrated into life, and undertook to provide an intellectual information flow with professional and commercial relationships, whose subjects and interest areas placed in our vocabulary.

The purpose of K3- "Raising individuals who know what they do, what imagine, and what can newly do according to the needs of the society in their live" is the third aim taking the highest score. When regarded to the elective courses according to this purpose the course taking the highest score is vocational English. Indisputably, English is an educational language. In the most prestigious schools of the world, education is given in English language. The most famous academic magazines are published in English. The newest and the most wonderful books are printed in English. Namely, for acquiring new skills and achieving the new information, English is obligatory. Moreover, the main resources in internet that is the most important information resource of today are English. The elective course taking the highest second score has been the course "Destination Management". It was accepted by many countries that tourism was an global economy industry, on which tourism concentrated on attracting tourist and addressing on the needs of tourist. Destination management forms the essence of this industry. This elective course can more significantly determine the need for raising individuals according to the requirements of the society. In the future, as the demand for destination increase, it is evident that the preferences of tourists will continue to increase. This demand increase will engender a competition between touristic destinations. It is a reality that tourism destinations will oblige to reveal the arguments making them different, in order to advantage over its competitors. A tourism student taking this course will graduate with this consciousness. When we regard to the other elective courses, they are put in order as "A2 - History of Anatolian Civilizations", "A5 - World Tourism Movements" and, "A3- Management of Customer relationships" 
K4-“. The matrix results formed for K4- criterion of that the course is for application in the tourism area are as follows.

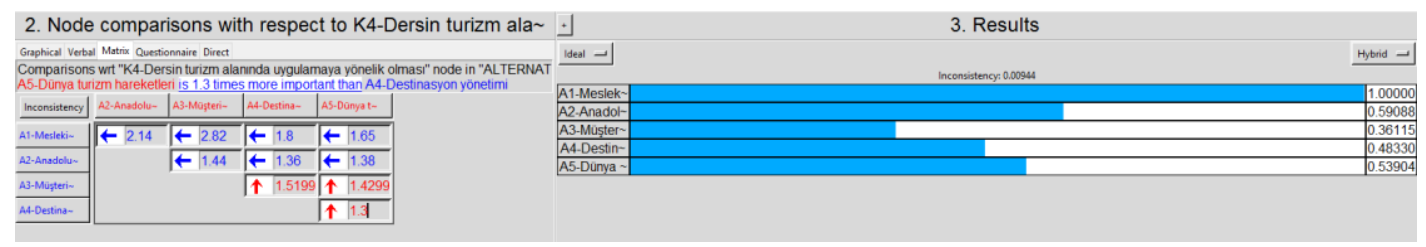

Figure 7 Display image of super decision program belonging to matrix table and prioritization results for K4- criterion

Table 7: Prioritization ordering of elective courses for K4-criterion

\begin{tabular}{|l|l|l|}
\hline \multicolumn{1}{|c|}{ Inconsistency } & \multicolumn{1}{|c|}{0.00944} & $\begin{array}{c}\text { K4-Dersin turizm } \\
\text { alaninda uygulamaya } \\
\text { yönelik olmast }\end{array}$ \\
\hline \multicolumn{1}{|c|}{ Name } & Normalized & \multicolumn{1}{c|}{ Idealized } \\
\hline A1- Vocational English & 0.336205854 & 1 \\
\hline A2- History of Anatolian Civilizations & 0.198657709 & 0.590881171 \\
\hline A5- World Tourism Movements & 0.181229474 & 0.539043184 \\
\hline A4- Destination Management & 0.162487207 & 0.483296781 \\
\hline A3- Management of Customer Relationship & 0.121419756 & 0.36114706 \\
\hline
\end{tabular}

Turkey 2023 Tourism Strategy, in which Turkey 2023 Tourism Project priorities to diversify tourism activities in the direction of the global tourism and development trends, is seen to target on creating increase in employment and income for every sector of the society through the increase occurring in tourism incomes with using and conserving the natural, cultural, historical, and geographical values in balanced way. When The purpose of $\mathbf{K 4}$ - "that the course is for application in the tourism area" is examined, a student graduated from Tourism Faculty should graduate by having to know who will be in which applications strategically. When elective courses are regarded in this direction of this aim, "Vocational English" got the highest score. This was followed by the course of "History of Anatolian Civilizations" and the course of "World Tourism Movements" that are in the second and third order". This course [in third order] will bring analysis ability in the student about the yesterday and today of world tourism movements. [The student] will have information about strategic management and quality management in tourism businesses and will reach the authority to manage service processes and affairs, which require the complex and unpredictable, and new strategic approaches related to his/her area. Another result attracting attention is that the course getting the least score is the course of "Management of Customer Relationships "for four different criteria as well. Although this course has a great importance to tourism student, it always got the last order among the other 5 courses. This course aims to get the student comprehend the management dimension of customer relationships and give 
the competencies that can account for the importance of the necessary communication.

\section{CONCLUSION AND SUGGESTIONS}

As a result of the study, of lecturers of Tourism Faculty, those being specialist in the area of business management expressed that they gave weight to the courses of Business Management, while those being specialist in the area of tourism concentrated on the courses of domain. Hence, tourism education can be foreseen to become interdisciplinary. Albeit tourism accepts natural resources as a basis for itself, it is seen that there is need for cooperating with the different disciplines for managing these resources in the best way.

The five elective courses getting the most point in the analysis carried out were analyzed according to four criteria determined. When the emerging results are evaluated, the selective course "Vocational English" took place in the first order according to the $\mathrm{K} 1, \mathrm{~K} 2, \mathrm{~K} 3$, and $\mathrm{K} 4$ criteria. The foreign language courses are to tourism education as both obligatory and selective courses. Since the language used the most commonly at these days, this course got the highest point. When regarded to the ordering of the other courses, the elective course "History of Anatolian Civilizations" took place in the second order for K1, K2, and K4 criteria. The reason for this is that lecturers can introduce that they believe in that "History of Anatolian Civilization" is important. In the third order, the course of "Destination Management" according to K1 and K3 criteria. The course "World Tourism Movements" showed its importance for K4. In the last order, the course "Management of Customer Relationships" take place. In terms of being able to make communications with the tourists, one of actors of tourism taking place in service sector, it can be said that this course is important.

The study has been carried out for the Department of Travel Business Management and Tour Guiding of Tourism Faculty and the survey was administered to total of 10 people among lecturers of Department of Travel Business and Tour Guiding and Tourism Business. It is considered that the results turning out in the study will be an example in the selection of courses of the departments of Travel Business and Tour Guiding, Travel Business, Tour Guiding of the different faculties. In addition, the other faculties and departments taking place in higher education will be able to also utilize this study.

Multiple Decision Technique used in the study enabled both quantitative data and qualitative data to be able to use in integrated way into each other. In case that quantitative data are not always present, qualitative data are also evaluated thanks to this method. The most important point is that that qualitative data accepted independently from each other will not be in fact independent from each other can be understood thanks to this method.

An element attracting attention in the study is that lecturers completing the survey reproaches in understanding the expression while dual pointing. It is recommended 
that it is appropriate for giving information [about AHP] before starting the study to the practitioners, who did not earlier work on AHP.

\section{REFERENCES}

Alkan, C., Doğan, H., ve Sezgin, S. İ. (1996). Mesleki ve teknik eğitimin esaslarl: kavramlar, gelişim, uygulamalar, yönelmeler: Ankara, Gazi Büro Kitabevi.

Demir, A. (1995). Akademik Danışmanların ve Öğrencilerin Akademik Danışmanlık Hizmeti İle İlgili Değerlendirmelerin Karşılştırılması. Türk Psikolojik Danışma ve Rehberlik Dergisi, 2(6), 22-28.

Demir, A. (1996). Üniversitedeki seçmeli ders uygulamasının öğrenciler ve öğretim üyelerince değerlendirilmesi. Türk Psikolojik Danısma ve Rehberlik Dergisi, 2(7).

Demir, A., ve Ok, A. (1996). Orta doğu teknik üniversitesindeki öğretim üye ve öğrencilerinin seçmeli dersler hakkındaki görüşleri. Hacettepe Üniversitesi Ĕ̆itim Fakültesi Dergisi, 12(12), 121-125.

EARGED. (2008). Seçmeli Derslerin Seçim Kriterlerinin Değerlendirilmesi Araştırması. Ankara:

Millî Eğitim Bakanlığg Eğitimi Araştırma Ve Geliştirme Dairesi Başkanlığ Retrieved from

https://www.meb.gov.tr/earged/earged/secmeli_dersler_arastirmasi.pdf.

Eşbahoğlu, F. (2015). İlköğretim 5 ve 6. Sinıflarda seçmeli derslerin seçim sürecinde karşılaşılan sorunlar ve çözüm önerileri. Ístanbul Aydın Üniversitesi Sosyal Bilimler Enstitüsü,(Yayımlanmamış Yüksek Lisans Tezi), İstanbul.

Evren, R., ve Ülengin, F. (1992). Yönetimde çok amaçll karar verme: İstanbul Teknik Üniversitesi.

Felek, S., Yuluğkural, Y., ve Aladağ, Z. (2007). Mobil iletişim Sektöründe Pazar Paylaşiminin Tahmininde AHP ve ANP Yöntemlerinin Kiyaslamasi. Endüstri Mühendisliği Dergisi, 18(1), 6-22.

Forman, E., ve Selly, M. (2002). Decision by Objectives. How to Convince Others that You Are Right,. 2nd. Edited by Co. Pte. Ltd: Singapore: World Scientific Publishing.

Genç, S. Z., ve Kalafat, T. (2007). Öğretmen Adaylarının Demokratik Tutumları İle Problem. Pamukkale Üniversitesi Ĕ̌itim Fakültesi Dergisi, 22(22), 10-22.

Güner, M., ve Yücel, Ö. (2007). Konfeksiyon Üretiminde Temel Kriterlerin Hiyerarşik Modellenmesi İle Üretilecek En Uygun Ürünün Belirlenmesi. Gazi Üniversitesi Mühendislik-Mimarlık Fakültesi Dergisi, 22(1).

Hacıŏlu, N. (1992). Yükseköğretimde mesleki turizm eğitimi geliştirme perspektifleri. Turizm Ĕ̌gitimi, Ankara, Turizm Bakanlı̆̆ Turizm Ĕgitimi Genel Müdürlüğü, Yorum Basın Yayın San. Ltd. Şti, 92.

Handfield, R., Walton, S. V., Sroufe, R., ve Melnyk, S. A. (2002). Applying environmental criteria to supplier assessment: A study in the application of the Analytical Hierarchy Process. European journal of operational research, 141(1), 70-87. 
Hergüner, G., ARSLAN, Ö. G. S., ve DÜNDAR, A. G. H. (2002). Beden eğitimi ve spor öğretmenliği bölümü öğrencilerinin okul deneyimi dersini algilama düzeyleri. Pamukkale Üniversitesi Eğitim Fakültesi Dergisi, 11(11), 44-58.

Kaplan, R. (2010). AHP Yöntemiyle Tedarikçi Seçimi: Perakende Sektöründe Bir Uygulama. (Yüksek Lisans Tezi), İstanbul Teknik Üniversitesi, Fen Bilimleri Enstitüsü.

Karslı, M. (2003). Öğretmenliğin temel kavramları. Öğretmenlik mesleğine giriş. Ankara.

Kocakalay, Ş., Özdemir, M. S., ve Işık, A. (2004). Analitik Serim Süreci İle Pazar Payı Tahmini. YA/EM XXIV. Ulusal Kongresi, Çukurova-Adana.

Kuzgun, Y., Pişkin, M., Sevim, S., Ersever, H., Akbalık, G., ve Hamamc1, Z. (1989). Ögrencilerin akademik danışmanlardan bekledikleri görevler ve danışmanların görev algıları. Yükseköğretimde Rehberlik ve Psikolojik Danışma Toplantısı. AÜ Eğitim Bilimleri Fakültesi Yayınları, 161, 115-126.

Misırlı, İ. (2002). Turizm sektöründe meslek standartları ve mesleki belgelendirme sistemi (Sertifikasyon). Anatolia Turizm AraG̦tırma Dergisi, 13(1), 39-55.

Özkan, Ö. (2007). Personel seçiminde karar verme yöntemlerinin incelenmesi: ahp, electre ve topsis örneği. Yüksek Lisans Tezi, Dokuz Eylül Üniversitesi, İzmir, Türkiye.

Paykoç, F., İçöz, N., ve Zorba, E. (1989). ODTÜ lisans programında verilen teknik nitelikte olmayan seçmeli derslerle İlgili bir çalışma. Yayınlanmamış ODTÜ Ĕ̈itim Fakülte Kurulu Komisyon Raporu.

Rençber, Ö. F. (2010). Büyük Çaplı Projelerde Karar Verme: Analitik Hiyerarşi Süreci Uygulaması. Gebze Yüksek Teknoloji Enstitüsü, Gebze.

Saaty, T. L. (1990). How to make a decision: the analytic hierarchy process. European journal of operational research, 48(1), 9-26.

Saaty, T. L. (2008). Relative measurement and its generalization in decision making why pairwise comparisons are central in mathematics for the measurement of intangible factors the analytic hierarchy/network process. RACSAM-Revista de la Real Academia de Ciencias Exactas, Fisicas y Naturales. Serie A. Matematicas, 102(2), 251-318.

Saaty, T. L., ve Vargas, L. G. (2012). Models, methods, concepts \& applications of the analytic hierarchy process (Vol. 175): Springer Science \& Business Media.

Sarıgöz, İ. H. (2009). Eğitimde çoklu mantık kurgusu ve kitlelere yansıtılması: yöntemsel bir bakış. Journal of Language and Linguistic Studies, 5(1), 90-96.

Sezgin, O. M. (2001). Genel Turizm ve Turizm Mevzuatt: Detay Yayıncılık.

Şahin, İ., ve Fındık, T. (2008). Türkiye'de Mesleki ve Teknik Eğitim: Mevcut Durum, Sorunlar ve Çözüm Önerileri. Türkiye Sosyal Araştırmalar Dergisi, 12/3(Aralik 2008), 65-86.

Tan, Ş., Kayabaşı, Y., ve Erdoğan, A. (2002). Öğretim Planlama ve Değerlendirme: Ankara: Anı Yayıncilık.

Taş, B. (2004). Seçmeli ders programlarının öğretmen ve öğrenci görüşleri doğrultusunda değerlendirilmesi. Basılmamış yüksek lisans tezi. Çukurova Üniversitesi, Adana. 
Tuyluoğlu, T. (2003). Türkiye'de Turizm Eğitiminin Niteliği. Ankara Üniversitesi, Sosyal Bilimler Enstitüsü, Halkla İlişkiler ve Tanıtım Ana Bilim Dall, Yüksek Lisans Tezi, Ankara.

Tümkaya, S. (1990). Akademik Danışmanlar ve Öğrencilerin Akademik Danışmanlık Görev Algıları ile Verilen Akademik Danışmanlık Hizmetlerini Değerlendirmeleri. Yayınlanmamış Yüksek Lisans Tezi, Çukurova Üniversitesi, Sosyal Bilimler Enstitusö, Adana.

Uyanık, E. (2005). Çok Kriterli Karar Alma Yöntemlerinin Tedarikçi Seçimi Problemine Uygulanması (Basılmamış Y. Lisans Tezi). Galatasaray Üniversitesi Fen Bilimler Enstitüsü, 12.

Ülgen, G. (1992). İlköğretim okullarının 6, 7, 8. sınıflarında seçmeli dersler. Hacettepe Üniversitesi Eğitim Fakültesi Dergisi, 8(8).

Üzümcü, T. P., ve Bayraktar, S. (2004). Türkiye'de Turizm Otel İşletmeciliği Alanında Eğitim Veren Yüksek Öğretim Kuruluşlarındaki Eğitimcilerin Turizm Mesleki Eğitiminin Etiksel açıdan İncelenmesine Yönelik Bir Alan Araştırması. 3. Ulusal Bilgi, Ekonomi ve Yönetim Kongresi Bildiri Kitabl, 80.

Variş, F. (1976). Eğitimde program geliş̧̧irme: teori ve teknikler: Ankara: Alkım Yayınları.

Woodhall, M. (1979). Education, Work and Employment In Developing CountriesA Synthesis of Recent Research. Education Work and Employment. A Summary Review. International Development Research Center Manuscript Reports. Ottowa: IDRC.

Yuluğkural, Y. (2001). Kocaeli'nde Deprem Sonrası Yerleşim Sorununa Çok Ölçütlü Yaklaşım. KOÜ Fen Bilimleri Enstitüsü, Yüksek Lisans Tezi (yayınlanmış), Kocaeli. 